\title{
THE EFFECT OF BLOCKED VERSUS RANDOM TRAINING SCHEDULES ON BOCCIA SKILLS PERFORMANCE IN EXPERIENCED ATHLETES WITH CEREBRAL PALSY Luke Morriss*, Julie Wittmannová**
}

\author{
* Faculty of Kinesiology and Rehabilitation Sciences, Catholic University, Leuven, Belgium \\ **Faculty of Physical Culture, Palacký University, Olomouc, Czech Republic
}

Efficiently maximizing sporting performances through structuring of training sessions has become a very important focus over the past twenty years. Very little study directly related to boccia exists for athletes with cerebral palsy (CP) and consequently information on performance measures is scarce. The aim of study was to measure the effect of blocked versus random training schedules on boccia skills performance. Fourteen experienced national-level athletes with $\mathrm{CP}(M=23.6$ years $)$ participated in this study. Athletes were divided in two intervention groups and followed prescribed blocked ( $n=$ seven athletes) and random $(n=$ seven athletes $)$ training schedules for 10 weeks. Data collection included pre- and post-tests original testing procedures. Two paired-samples Wilcoxon Signed Rank tests and a Mann-Whitney $U$ test only generated statistically significant evidence to support blocked training $\left(z=2.29, p=0.02, C I_{.90}=9.50,22.50\right)$. Despite this, findings and individual cases of improvements plus athletes and coaches remarks indicated a practical significance towards blocked training schedules over random training schedules in terms of improving boccia skills performance. Greater gains across all three boccia skills measured and in total mean difference between pre- and post-test were shown in favor of athletes following blocked training schedules.

KEYWORDS: Cerebral palsy (CP), boccia, motor skills, performance, blocked and random training schedules

\section{INTRODUCTION}

Organized sports for persons with cerebral palsy (CP) were slower to both gain attention and develop when compared to other disability sports. However, individuals with $\mathrm{CP}$ have shown to be able to compete and the number of athletes with $\mathrm{CP}$ worldwide grows and continues to grow (Jones, 1988; Čurdová, 2005). Furthermore, over the past twenty years, substantial increases in the levels of government and private support have seen numerous, consistent and improved performances of many athletes and teams (Doll-Tepper, 1999; DePauw \& Gavron, 2005). Consequently, maximizing sporting performances in the most efficient way has become a very important focus for many athletes and coaches.

A large amount of study has been done on how motor skill acquisition and development is affected by the organization of practice schedules (Magill \& Hall, 1990; Shea \& Morgan, 1979 in Hynes-Dusel, 2002). In particular, focus has been on how practice or training sessions should be structured to result in the greatest and most efficient improvement. It is generally accepted that the total amount of practice is the most important factor to consider (Schmidt \& Lee, 1999 in Choi, Qi, Gordon \& Schweighofer, 2008). In addition, literature suggests practice should be randomized, which degrades performance during practice but improves performance over time in retention tests when compared to blocked practice (Schmidt, 1991; Hanlon, 1996).

However, the question remains if these findings for training and motor skill development also apply for athletes with disabilities, in particular individuals with CP. Currently, very few studies directly relating to CP and boccia exists (Marta, 1998) and as a 
result, information relating to measures of performance is limited. Boccia is a game designed for people for $\mathrm{CP}$ and is a cross between petanque and indoor bowls that can be played as individuals, and in pairs or teams. The aim of boccia is to propel (by throwing, kicking or using a ramp device with use of an assistant) your colored boccia balls closer to the white jack than your opponents. For competition purposes, players are classified into one of the boccia sport-specific classes $\mathrm{BC} 1, \mathrm{BC} 2, \mathrm{BC} 3$ or $\mathrm{BC} 4$ (CPISRA, 2010).

The aim of the current study was to identify the effect of blocked versus random training schedules on boccia skills performance in persons with $\mathrm{CP}$ by measuring (1) jack and first ball placement, (2) drawing shots, and (3) driving shots skill performances. The jack and first ball refers to the first shot of the game, while drawing and driving refer to throwing to score points and throwing to hit and move boccia balls respectively. The current study will, in practice, provide boccia players and coaches with further explanations relating to optimal training schedules and implications for practice, improvement and performance.

Consequently, the following research questions were derived: (1) whether blocked training schedules improve boccia skills performance, (2) whether random training schedules improve boccia skills performance, and (3) whether there is a difference between blocked and random training schedules in relation to improving boccia skills performance.

\section{METHOD}

\section{Participants}

Fourteen experienced national-level athletes with $\mathrm{CP}$, comprised of nine males and five females, participated in this study, ages ranging from 17 to 40 years $(\mathrm{M}=23.6$ years; $\mathrm{SD} \pm 6.9$ years). The athletes were based in two major sports clubs in the Czech Republic: Kociánka Brno, o.s (SKK Brno) and Tukani APA VČAS Olomouc, as well as one participant from the ParaFed Canterbury boccia club in Christchurch, New Zealand.
The inclusion criteria included the provision of informed consent coupled with the mostrecent classification as determined by the CPISRA (2010) classification rules for classes $\mathrm{BC} 1, \mathrm{BC} 2$, and $\mathrm{BC} 3$.

\section{Measurements and study design}

To determine the effect of blocked and random training schedules on boccia performance, original testing and intervention procedures were used as there has been little previous research into the area of $\mathrm{CP}$ and boccia performance measures to date. This testing procedure was developed and trailed within the New Zealand boccia team over the past seven years and has been beneficial in skill improvement, tracking progress and evaluating training. The testing procedure measures three components: (1) jack and first ball placement, (2) drawing shots, and (3) driving shots, and requires participants to propel 84 boccia balls for a combined total possible maximum score of 252 . The reason for propelling 84 boccia balls are so that scores aren't based on chance and fatigue is accounted for as consistency is needed to obtain a high skill performance score. A twogroup (blocked and random) pre-test and post-test designed study (Portney \& Watkins, 2009) was used that follows CPISRA (2010) international boccia rules at all times during both testing and intervention. The two boccia skills performance assessments (pre- and post-tests) and intervention training sessions were done over a period of 10 weeks. The reason for using the pre- and post-tests was to measure if there is an actual difference, if any, between blocked and random training schedules both before and after the training intervention programs in relation to boccia skills performance. An initial pre-test was done to determine a starting boccia skills test score for each athlete. Half of the total number of athletes, both within a classification grade and overall, were then randomly assigned to one of the experimental training schedule groups to follow the respective intervention training programs. This was followed by a post-test using the same matched testing protocol to determine a 
final performance score and data for analysis purposes.

\section{Testing protocol}

Athletes were given an outline of the testing procedure prior to commencing testing. During testing athletes were to sit inside one of the two central playing boxes. The authors were present and conducted the (pre- and post-) testing procedure with assistance of the club coaches (all with international and Paralympic Games boccia experience) at their respective clubs. The same boccia balls, equipment (assistive devices), venues and testing protocol were used in both the pre- and post-test for each athlete.

(1) The first part of the test measured jack ball placement and the first ball shot. To score, athletes were required to propel the jack anywhere within the scoring dimensions of the court. If the jack failed to meet this criterion then no points could be scored on this attempt. Once the jack ball had been achieved, athletes were to follow this shot up by propelling one colored boccia ball as close to the jack as possible. If the colored boccia ball ended up within one ball width $(9.0 \mathrm{~cm})$ three points were scored; within two ball widths $(18.0 \mathrm{~cm})$ - two points were scored; within three ball widths $(27.0 \mathrm{~cm})$ - one point was scored; and anything outside of this range scored zero. After these two shots had been thrown, the boccia balls were retrieved and returned to the athlete to be repeated twelve times with the chance to score a maximum 36 points.

(2) The second part of the test measured the ability to draw onto the jack ball at three different set lengths of three, five and nine meters. The jack was initially placed directly in front of the used playing box at three meters, while each athlete had one colored boccia ball with which they were to propel as close as possible to the jack. The same threepoint scoring system was used. This was repeated twelve times with a possible maximum score of thirty six, and then the jack was moved back to five meters, followed by nine meters respectively, and the same procedure repeated. The total maximum score possible for the drawing section of the test was 108.

(3) The third and final part of the test measured the ability to drive the jack away at three different set lengths of three, five and nine meters. The jack was again placed directly in front of the used playing box at three meters, while the athlete had one colored boccia ball with which they were to propel and hit the jack off the original mark as far as possible. This time, if the jack is moved three or more ball widths $(27.0 \mathrm{~cm})$ from the original position - three points were scored; moved two ball widths $(18.0 \mathrm{~cm})$ - two points were scored; moved one ball width $(9.0 \mathrm{~cm})$ one point was scored; and no contact or moving the ball less than $9.0 \mathrm{~cm}$ scored zero. This was repeated twelve times with a possible maximum score of thirty six, and then the jack was moved back to five meters, followed by nine meters respectively, and the same procedure repeated. The total maximum score possible for the driving section of the test is 108 .

A modified ruler with three distance markings of $9.0 \mathrm{~cm}, 18.0 \mathrm{~cm}$ and $27.0 \mathrm{~cm}$ was used to determine the score for each shot measured during testing. Measurements were always taken from the closest outermost edge of the target jack boccia ball to the furthest outermost edge of the propelled colour boccia ball.

\section{Intervention}

All athletes received a prescribed blocked or random training intervention schedule to follow for 10-weeks with training sessions lasting 90 minutes each twice a week. Every training session consisted of: (1) jack and first ball practice, (2) drawing practice, and (3) driving practice activities. All were explained in simple text with pictures to follow. Athletes following the prescribed blocked training schedule repeatedly performed each individual skill: (1) jack and first ball placement, (2) drawing shots, or (3) driving shots, for 10 minutes at each length of three meters, five meters and nine meters respectively before changing skill. Conversely, athletes following the random 
training schedule performed each individual skill: (1) jack and first ball placement, (2) drawing shots, or (3) driving shots, for the same time of 30 minutes per skill, but instead varied the length for each attempt before changing skill (Schmidt \& Wrisberg, 2008). The training schedules and activities were designed and modified based on the authors' international and Paralympic Games boccia coaching experience. Prior to the first training intervention sessions, the authors held oneon-one workshop sessions with the respective club coaches explaining the aims and reasons of the study and why the training programs have been designed. The session also included specific step-by-step instructions and practical guides on how to run the respective training activities. In addition, the participating clubs were each given personal printed and electronic copies of the blocked and random training schedules along with the athletes' names and their respective schedules to follow. The first training sessions with the athletes were jointly-run by the authors and coaches to demonstrate and explain the training procedures to the athletes. The authors continued to coach and monitor eight athletes who were based in Olomouc, whereas the club coaches coached the Brno and Canterbury based athletes respectively. Weekly email and phone contact was maintained with the Brno and Canterbury club coaches to monitor the prescribed twicea-week training sessions for athletes. Furthermore, the authors visited the Brno club every third week (a total of five visits including pre- and post-tests) to personally check the prescribed training schedules.

\section{Data analysis}

Two separate paired-samples Wilcoxon Signed Rank Tests were used (one for blocked and one for random training) to determine whether blocked and random training schedules respectively improved boccia skills performance between pre- and post-tests. A two-sample Mann-Whitney U test was used to determine whether there was a difference between blocked and random training schedules in terms of an increase in individual and combined boccia skills performance. The non-parametric tests were used due to the small sample sizes.

\section{RESULTS}

Table 1 presents the details of classification grade, age, gender, training schedule, sum results for pre- and post-test scores for each of the athletes, and the mean scores and SDs for blocked and random training schedules respectively. It can be seen that all athletes, except three (athletes 7, 11 and 12), improved in overall boccia skills performance following intervention. The most relevant statistics for analysis purposes are the means reflecting the pre- and post-test scores for blocked and random training schedules. Examination between these scores show the difference in mean sum results of the blocked training schedule group $(M=15.43, S D=$ 4.77) was greater than the difference in mean sum results of the random training schedule group $(M=4.43, S D=1.93)$. With $90 \%$ confidence, the median for total scores following blocked training is somewhere between 9.50 and 22.50 points higher than the median total score prior to blocked training. A $90 \%$ confidence interval was used as the authors were unable to assume that the score differences came from a normal distribution and that the sample size was too small to construct a $95 \%$ confidence interval.

The sum breakdown of boccia skills results for pre- and post-test scores for each of the athletes relative to training schedule are shown in Table 2. Mean differences between pre- and post-test scores for the blocked training schedule group compared to the random training schedule group were: improvements of 5.57 versus 1.71 for jack and first ball; improvements of 5.43 versus 3.86 for drawing skills; and improvement of 3.86 versus a decline of 1.14 for driving skills.

Table 3 presents the results of two pairedsamples Wilcoxon Signed Rank tests, comparing the differences for blocked and random training schedules pre- and post- tests scores respectively. Participants undergoing 
blocked training improved significantly overall $\left(z=2.29, p=0.02, C I_{.90}=9.50\right.$, 22.50).

The results of a 2-sample Mann-Whitney $\mathrm{U}$ test $(p<0.05)$ comparing the differences in the three boccia skills tested: (1) jack and first ball, (2) drawing, and (3) driving, as well as the total score between pre- and post- tests between blocked and random training schedules are shown in Table 4. No statistical differences were demonstrated between blocked and random training schedules for any of the three boccia skills tested, nor for the overall score.

Table 1

Athlete Characteristics, Intervention Training Schedule and Results from Pre- and Post-Tests

\begin{tabular}{|c|c|c|c|c|c|c|}
\hline Athlete & $\begin{array}{c}\text { Class } \\
\text { (CPISRA) }\end{array}$ & $\begin{array}{c}\text { Age } \\
\text { (years) }\end{array}$ & Gender & $\begin{array}{l}\text { Training } \\
\text { schedule }\end{array}$ & $\begin{array}{c}\text { Pre-test } \\
\text { (sum) }\end{array}$ & $\begin{array}{c}\text { Post-test } \\
\text { (sum) }\end{array}$ \\
\hline 1 & $\mathrm{BC} 2$ & 17 & Male & Blocked & 52 & 64 \\
\hline 2 & $\mathrm{BC} 2$ & 20 & Male & Random & 38 & 64 \\
\hline 3 & $\mathrm{BC} 2$ & 18 & Male & Blocked & 26 & 43 \\
\hline 4 & $\mathrm{BC} 2$ & 23 & Male & Blocked & 126 & 139 \\
\hline 5 & $\mathrm{BC} 3$ & 26 & Female & Blocked & 96 & 124 \\
\hline 6 & $\mathrm{BC} 2$ & 17 & Female & Random & 78 & 86 \\
\hline 7 & $\mathrm{BC} 3$ & 24 & Male & Random & 54 & 46 \\
\hline 8 & $\mathrm{BC} 2$ & 17 & Male & Blocked & 32 & 39 \\
\hline 9 & $\mathrm{BC} 3$ & 40 & Male & Random & 101 & 116 \\
\hline 10 & $\mathrm{BC} 3$ & 17 & Male & Blocked & 153 & 177 \\
\hline 11 & $\mathrm{BC} 3$ & 25 & Female & Random & 102 & 100 \\
\hline 12 & $\mathrm{BC} 2$ & 27 & Female & Random & 61 & 51 \\
\hline 13 & $\mathrm{BC} 2$ & 26 & Female & Random & 71 & 73 \\
\hline 14 & $\mathrm{BC} 2$ & 34 & Male & Blocked & 66 & 73 \\
\hline$M$ & & 23.6 & & Blocked & $\begin{array}{c}78.71 \\
(48.11)\end{array}$ & $\begin{array}{c}94.14 \\
(52.88)\end{array}$ \\
\hline$(S D)$ & & (6.9) & & Random & $\begin{array}{c}72.14 \\
(23.73)\end{array}$ & $\begin{array}{c}76.57 \\
(25.66)\end{array}$ \\
\hline
\end{tabular}


Table 2

Athlete Intervention Schedule and Boccia Skills Results from Pre- and Post-Tests

\begin{tabular}{|c|c|c|c|c|c|c|c|}
\hline \multirow[t]{2}{*}{ Athlete } & \multirow{2}{*}{$\begin{array}{l}\text { Training } \\
\text { schedule }\end{array}$} & \multicolumn{3}{|c|}{ Pre-test } & \multicolumn{3}{|c|}{ Post-test } \\
\hline & & $\begin{array}{l}\text { Jack and } \\
\text { first ball }\end{array}$ & Drawing & Driving & $\begin{array}{l}\text { Jack and } \\
\text { first ball }\end{array}$ & Drawing & Driving \\
\hline 1 & Blocked & 8 & 14 & 30 & 16 & 22 & 26 \\
\hline 2 & Random & 6 & 22 & 10 & 12 & 32 & 18 \\
\hline 3 & Blocked & 5 & 16 & 5 & 1 & 28 & 14 \\
\hline 4 & Blocked & 9 & 69 & 48 & 31 & 60 & 48 \\
\hline 5 & Blocked & 11 & 34 & 51 & 7 & 41 & 76 \\
\hline 6 & Random & 8 & 39 & 31 & 15 & 29 & 42 \\
\hline 7 & Random & 1 & 5 & 48 & 7 & 14 & 25 \\
\hline 8 & Blocked & 7 & 12 & 13 & 17 & 12 & 10 \\
\hline 9 & Random & 16 & 45 & 40 & 16 & 52 & 48 \\
\hline 10 & Blocked & 19 & 55 & 79 & 23 & 71 & 83 \\
\hline 11 & Random & 13 & 35 & 54 & 15 & 35 & 50 \\
\hline 12 & Random & 12 & 20 & 29 & 4 & 31 & 16 \\
\hline 13 & Random & 14 & 37 & 20 & 13 & 35 & 25 \\
\hline 14 & Blocked & 13 & 21 & 32 & 16 & 25 & 32 \\
\hline \multirow{2}{*}{$\begin{array}{c}M \\
(S D)\end{array}$} & Blocked & $\begin{array}{l}10.29 \\
(4.65)\end{array}$ & $\begin{array}{c}\mathbf{3 1 . 5 7} \\
(\mathbf{2 2 . 3 7 )}\end{array}$ & $\begin{array}{c}36.86 \\
(25.02)\end{array}$ & $\begin{array}{l}15.86 \\
(9.84)\end{array}$ & $\begin{array}{c}37.00 \\
(21.51)\end{array}$ & $\begin{array}{c}41.29 \\
(28.96)\end{array}$ \\
\hline & Random & $\begin{array}{l}10.00 \\
(5.26)\end{array}$ & $\begin{array}{c}29.00 \\
(13.92)\end{array}$ & $\begin{array}{c}33.14 \\
(15.45)\end{array}$ & $\begin{array}{l}11.71 \\
(4.54)\end{array}$ & $\begin{array}{c}32.86 \\
(11.19)\end{array}$ & $\begin{array}{c}32.00 \\
(14.32)\end{array}$ \\
\hline
\end{tabular}

Table 3

Results of Paired-Samples Wilcoxon Signed Rank Test for Differences between Respective Blocked and Random Training Schedules Pre- and Post- Tests Scores

\begin{tabular}{cccccc}
\hline \multicolumn{2}{c}{ Blocked } & \multicolumn{5}{c}{ Random } \\
Skill & $\mathbf{z}$ & $\boldsymbol{p}$ & Skill & $\mathbf{z}$ & $\boldsymbol{p}$ \\
\hline Jack and first ball & 1.28 & 0.20 & Jack and first ball & 0.63 & 0.53 \\
Drawing & 1.26 & 0.21 & Drawing & 1.05 & 0.29 \\
Driving & 0.95 & 0.34 & Driving & 0.00 & 1.00 \\
Total & 2.29 & 0.02 & Total & 0.59 & 0.55
\end{tabular}

Note. All mean ranks (pre- and post-) have been omitted

\section{Table 4}

Results of 2-Samples Mann-Whitney U Test for Differences between Blocked and Random Training Schedule Pre- and Post- Tests Scores

Skill

Mean ranks

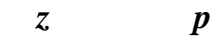

\begin{tabular}{ccccc}
\cline { 2 - 3 } & Blocked & Random & & \\
Jack and first ball & 6.57 & 8.43 & 0.77 & 0.44 \\
Drawing & 7.07 & 7.93 & 0.32 & 0.75 \\
Driving & 6.71 & 8.29 & 0.64 & 0.52 \\
\hline Total & 5.71 & 9.29 & 1.53 & 0.12
\end{tabular}




\section{DISCUSSION}

Although differences between the effects of blocked versus random training schedules from the current study were not statistically significant, the greater gain in mean sum results in boccia skills performance were shown by athletes using the blocked training schedule versus athletes using the random training schedule indicating a practical significance. Furthermore, the three athletes (7, 11 and 12) who did not improve on their pre-test scores each followed the random training schedule; while the greatest and worst improvements (athletes 5 and 12) followed blocked and random training schedules respectively (see Table 1).

It is evident that the blocked training schedule group, on average, showed greater gains across all three boccia skills measured when compared to the random training schedule group (see Table 2). It is also important to note that the random training group on average declined in the driving category indicating that random training is detrimental to the performance of this boccia skill. This suggests that athletes following the random training schedule found it difficult to adjust to the changing conditions (length) of each shot, as opposed to the repetition of the blocked training schedule group. These findings challenge the beliefs (Schmidt, 1991; Hanlon, 1996) that random training is more beneficial to improvement and learning than blocked training. However current findings are consistent with Giuffrida, Shea \& Fairbrother (2002) who showed that blocked training was most beneficial when repeatedly learning a task in the same way it is performed. Results from the current study reinforce the idea that individuals with specific neurologic impairments and disabilities, in this case $\mathrm{CP}$, require blocked training to learn more effectively as they are unable to process too much information at once (Lin, Sullivan, Wu, Kantak \& Winstein, 2007), such as choosing the parameters for the type of shot needed between a blocked and random training schedule.

The current study used two training schedule interventions that proved somewhat effective in improving boccia skills performance in athletes with CP. While the $p$ value for the blocked training schedule total between pre- and post-tests for the intervention was statistically significant (see Table 3); no statistical significance was observed for the random training schedule (see Table 3), nor the difference between blocked and random training schedules (see Table 4) in relation to improving boccia skills performance. The comparison between preand post- test scores for athletes following the blocked training schedule shows evidence to suggest that the median total score after blocked training is higher than the median total score before training.

Despite findings that the blocked training schedule improves the overall boccia skills performance score, the authors were unable to specify which area of the athletes' game improved, as the authors were unable to find significant differences for any of the three individual skill areas between the pre- and post- tests. A possible explanation for this is that two or three of the three skills: (1) jack and first ball, (2) drawing and (3) driving improved, but not enough for a significant difference between pre- and post- test scores for these skills to be found. However, when the differences were added together for a total score, the accumulative improvement in the three skill areas leads to a difference between the pre- and post-tests that was large enough to find a significant effect for blocked training. With a larger sample size, it is likely that the authors would be able to establish which particular area(s) improved following blocked training. However, there was no evidence to suggest a significant difference between median total scores before and after random training, nor was there any significant evidence that the median total score after random training was the same as the median total score after blocked training. Lack of statistical significance may be due to a small sample size.

This study only assessed three skills: (1) jack and first ball, (2) drawing, and (3) driving in boccia performance in experienced national level athletes with CP. Other findings 
can also be counted in from the current research in terms of boccia skills: it is important to emphasize training of boccia skills played at longer distances and playing in the farthest part of the boccia court as the measurements taken for longer distances were lower compared to shorter distances; males and females are capable of obtaining similar scores in boccia skills performances; better measurement results (test scores) were obtained in the pre- and post-tests for BC3 players using assistive devices when compared to $\mathrm{BC} 2$ throwing players. These are additional areas that require more attention and should be further examined in the future.

The first and most important limitation was that this study only involved fourteen athletes. Consequently, a small sample size makes it more difficult to produce findings of statistical significance as statistical tests normally require a larger sample size to justify that the effect did not just happened by chance alone. Provided that the current findings were replicated with a larger sample size, results may have been found statistically significant. Generalization of the current findings should therefore be undertaken with caution because of the relatively small sample size and restricted number of retention tests. Consequently, more well-controlled studies using longitudinal data, larger sample sizes, more tests and an additional experimental control group would be helpful to track the changes in boccia performance over time relative to both training schedules. This would also help remove the variability of results due to the nature and degree of CP.

Secondly, this study only involved experienced athletes. Findings from Painter, Inman and Vincent (1994) showed that it is more difficult to detect changes in learning and performance in subjects with a mild intellectual disability who were already somewhat competent and skilled with a set motor task. Therefore, this test should be repeated with a larger population of differing skill levels and competition, including a sample size of equal numbers for males and females, and classification groups, to ensure suitable data for statistical analysis between beginner, advanced and expert players and types of training.

Thirdly, due to practicality issues such as travel and costs within the limited amount of time available to execute this study, the intervention training periods were not able to be run for long enough to yield more reliable data, hence the statistical insignificance in the results. In addition, this research was only conducted in two sports clubs in the Czech Republic.

Furthermore, as boccia is a minority sport, there are a limited number of coaches and support assistants which affects the amount of time that athletes can spend practicing. Therefore, in order to achieve a stronger overall understanding of the effect of blocked versus random training schedules on boccia performance in persons with $\mathrm{CP}$, it would be necessary to complete similar research in a number of different clubs and athletes across the country. It would also be worthwhile to conduct a cross-cultural research by testing players from different countries to gain a better understanding on boccia skills performances worldwide.

Previous literature and findings have suggested that blocked training provide better learning results, especially during the skill acquisition phase (Magill \& Hall, 1990; Shea \& Morgan, 1979 in Hynes-Dusel, 2002). Traditionally, teachers and coaches begin teaching motor skill performance with an aim on improving technique through the use of a blocked training schedule so the beginning learner can gain proficiency in the skill itself before they are forced to apply this into a more challenging game-like situation. This is generally followed by a more random training schedule once the learner has become competent and confident in their performance of the motor skills. Therefore, the application of advanced skills and strategy may become more of a focus, suggesting that there is a place for both blocked and random training schedules in sport (Schmidt \& Wrisberg, 2008).

However, design limitations notwithstanding, it can be concluded that blocked training schedules were practically 
significant in improving boccia skills performance versus random training schedules based on the statistical evidence to support blocked training improvements as well as individual cases of improvements, researcher training observations, and discussion with athletes and coaches.

Maximizing sporting performances in the most efficient way has become an increasingly important focus throughout the world. It is therefore necessary to have knowledge on how to structure training sessions to improve the consistency of skill levels and performances in athletes. Although there has been research into the areas of training schedules and types of practice, there has been little previous research directly related to skill techniques or performance measures in boccia in athletes with CP. To conclude, findings from the current study provide an insight into training and motor skill development and how these apply to athletes with $\mathrm{CP}$ in terms of skill performances in boccia. It also addresses some of the gaps in the literature concerning disability sports.

\section{REFERENCES}

Cerebral Palsy International Sport and

Recreation Association (CPISRA). (2010).

CPISRA sports manual (10 ${ }^{\text {th }} \mathrm{ed}$.). [Online].

Available URL:

http://www.cpisra.org/files/manual10 9p/C PISRA Sports Manual 10th Edition Rele ase 00927 October 2010.pdf Retrieved 19/11/2010.

Choi, Y., Qi, F., Gordon, J., \& Schweighofer, N. (2008). Performance-based adaptive schedules enhance motor learning. Journal of motor behaviour, Vol. 40 No. 4, pp. 273280.

Čurdová, J. (2005). Hodnocení sebevědomí u dětí s dětskou mozkovou obrnou. (Selfconfidence classification of children with cerebral palsy), Dissertation work, Univerzita Palackého, Olomouc.

DePauw, K., \& Gavron, S. (2005). Disability sport $\left(2^{\text {nd }}\right.$ ed.). Human Kinetics Publishers.

Doll-Tepper, G. (1999). The international politics of sport in the twentieth century in
Riordan, J., \& Kruger, A (eds.). Taylor \& Francis group.

Giuffrida, C.G., Shea, J.B., \& Fairbrother, J.T. (2002). Differential transfer benefits of increased practice for constant, blocked, and serial practice schedules. Journal of motor behavior, Vol. 34, No. 4, pp. 353-365.

Hanlon, R.E. (1996). Motor learning following unilateral stroke. Arch Phys Med Rehabil, Vol. 77, pp. 811-815.

Hynes-Dusel, J.M. (2002). Practice and motor learning. Physical Educator Spring 2002: Vol. 59, issue 2, pp. 58-66.

Jones, J.A. (1988). Sports opportunities for individuals with cerebral palsy: A brief historical perspective in Jones, J. A (ed.) Training guide to cerebral palsy sports (3rd ed.). Human Kinetics Books, Champaign, IL, pp. 3-8.

Lin, CH., Sullivan, K.J., Wu, A.D., Kantak, S., \& Winstein, C.J. (2007). Effect of task practice order on motor skill learning in adults with Parkinson disease: a pilot study. Physical therapy, Vol. 87, No. 9, pp. 11201131.

Magill, R.A., \& Hall, K.G. (1990). A review of the contextual interference effect in motor skill acquisition. Human movement sciences, Vol. 9, pp. 241-289.

Marta, L. (1998). Estudo piloto sobre o estudo do cohecimento na modalidade de Boccia (Boccia pilot study about the state and knowledge of the sport). Master thesis in Sport Sciences, University of Oporto, Portugal.

Painter, M.A., Inman, K.B., \& Vincent, W.J. (1994). Contextual interference effects in the acquisition and retention of motor tasks by individuals with mild mental handicaps. Adapted physical activity quarterly, Vol. 11, pp. 383-395.

Portney, L., \& Watkins, M. (2009). Foundations of clinical research: applications to practice ( $3^{\text {rd }}$ ed.). Pearson Prentice Hall.

Schmidt, R.A. (1991). Motor learning principles for physical therapy in M.J. Lister (ed.), Contemporary management of motor control problems: proceedings of the II- 
STEP conference (pp. 49-63). Alexandria, VA: Foundation for Physical Therapy.

Schmidt, R., \& Wrisberg, C. (2008). Motor learning and performance: A situationbased learning approach. (4 $4^{\text {th }}$ ed.). Human Kinetics Publishers.
Corresponding author's e-mail address: luke_morriss@hotmail.com

\title{
DIE AUSWIRKUNGEN VON GEBLOCKTER IM VERGLEICH ZU ZUFÄLLIG VERTEILTER TRAININGSEINTEILUNG AUF DIE ERBRINGUNG DER BOCCIALEISTUNG BEI ERFAHRENEN ATHLETEN MIT CERBRALER BEWEGUNGSSTÖRUNG
}

(Abstract)

Die effiziente Maximierung der sportlichen Leistung durch die Strukturierung der Trainingseinheiten ist in den letzten zwanzig Jahren ein wichtiger Punkt der Aufmerksamkeit geworden. Es gibt nur wenige Studien, die sich direkt auf Boccia für Athleten mit cerebraler Bewegungsstörung (CP) beziehen und somit ist Wissen über Leistungsgrößen rar. Die Absicht der Studie war es, die Auswirkung von geblockten im Vergleich zu zufällig angesetzten Trainingseinheiten auf die Leistung in den Boccia-Fertigkeiten zu messen. Die Sportler wurden in zwei Interventionsgruppen geteilt und folgten einerseits dem vorgeschriebenen geblockten $(\mathrm{n}=$ sieben Athleten) und andererseits einem randomisierten $(\mathrm{n}=$ sieben Athleten) Trainingseinheiten über 10 Wochen. Die Datenerhebung erfolgte in den Prä- und Post-Tests nach einer originalen Testprozedur. Zwei paarweise erhobene Stichproben ergaben im Wilcox Signed Ranking Tests und im Mann-Whitney U-Test ein nur statistisch signifikantes Ergebnis zugunsten des geblockten Trainings $\left(z=2.29, p=0.02, C I_{.90}=9.50,22.50\right)$. Dennoch ergeben Studien und Einzelfälle von Verbesserungen sowie Anmerkungen von Sportler(inne)n und Trainer(inne)n aus der Praxis eine stichhaltige Bevorzugung für eine geblockten Trainingseinteilung gegenüber zufällig angeordneten Trainingseinheiten bezogen auf die Verbesserung der spezifischen Boccia-Fertigkeiten. Es ergaben sich größere Zugewinne in allen drei gemessenen Boccia-Fertigkeiten und ein Unterschied im Gesamtdurchschnitt zwischen Prä- und Post-Test zugunsten der Athleten, die dem geblockten Trainingsplan gefolgt waren.

SCHLÜSSELWÖRTER: Cerebralparese (CP), Boccia, Bewegungsfertigkeiten, Leistung, geblockte und randomisierte Trainingseinteilung

\section{LES EFFETS D'UN ENTRAINEMENT STRUCTURÉ ET D'UN ENTRAINEMENT NON STRUCTURE SUR LA PERFORMANCE EN BOCCIA CHEZ DES ATHLETES EXPERIMENTÉS INFIRMES MOTEURS CÉRÉBRAUX}

\author{
(Résumé)
}

L'optimisation de la performance à travers la structuration de l'entrainement a pris une grande importance ces vingt dernières années. Très peu d'études liées à la pratique de la boccia, sport pratiqué par des infirmes moteurs cérébraux (IMC), existent et par conséquent rares sont les informations sur les évaluations de la performance. Le but de cette étude était d'évaluer les effets d'un programme d'entrainement non structuré et d'un programme structuré sur les performances en boccia. 14 athlètes IMC (âge moyen : 23,6 ans), expérimentés, de niveau national ont participé à cette étude. Les athlètes ont été divisés en 2 groupes de 7 participants chacun et ont reçu soit le 
programme d'entrainement structuré soit le programme d'entrainement non-structuré pendant 10 semaines. Les données ont été collectées avant et après intervention. Seulement les tests de Wilcoxon pour échantillons appariés et de Mann-Whitney ont montré une différence significative en faveur de l'entrainement structuré $\left(z=2.29, p=0.02, C I_{.90}=9.50,22.50\right)$. Malgré ces résultats, l'amélioration des performances individuelles pour certains athlètes additionnée aux remarques des coachs indiquent une supériorité pratique de l'entrainement structuré dans le cadre de l'amélioration des performances en boccia. Les meilleures améliorations pour les 3 aptitudes évaluées et les différences des valeurs moyennes avant et après intervention ont été démontrées pour les athlètes suivant un programme d'entrainement structuré.

MOTS CLES: Infirme Moteur Cérébral (IMC), boccia, performance motrice, programme d'entrainement structuré et aléatoire.

\title{
ЭФФЕКТИВНОСТЬ СТРОГО РЕГЛАМЕНТИРОВАННОГО МЕТОДА ПО СРАВНЕНИЮ С ПРОИЗВОЛЬНЫМ РЕЖИМОМ ТРЕНИРОВКИ ПО БОЧЧЕ КВАЛИФИЦИРОВАННЫХ СПОРТСМЕНОВ С ЦЕРЕБРАЛЬНЫМ ПАРАЛИЧОМ
}

\author{
Аннотацця
}

Максимизация спортивных достижений посредством структурирования учебных занятий стало очень важным направлением в течение последних двадцати лет. В настоящее время существует очень мало исследований в области бочче по отношению к спортсменам с церебральным параличом (ЦП). Целью исследования стало измерение эффективности строго регламентированного метода тренировки по бочче в соотношении с произвольным режимом. В этом исследовании приняли участие четырнадцать квалифицированных спортсменов с ЦП $(\mathrm{M}=23,6$ лет). Они были разделены на две группы: семь спортсменов следовали определенному графику, и еще семь тренировались произвольно на протяжении 10 недель. Собранные данные включают пре- и пост-тестирование по оригинальным методикам. Только одна пара подопытных показала статистически существенные результаты в поддержку строго регламентированного метода тренировки $(\mathrm{z}=2.29, \mathrm{p}=0.02, \mathrm{CI} .90=9.50,22.50)$. Но, не смотря на это, конечные данные, отдельные случаи и показания тренеров указывали на практическую значимость именно строго регламентированного метода тренировки в контексте совершенствования навыков игры в бочче.

КЛЮЧЕВЫЕ СЛОВА: Церебральный паралич (ЦП), бочче, двигательные навыки, строго регламентированный метод и произвольный режим

\section{EL EFECTO DE HORARIOS DE ENTRENAMIENTO FIJOS VERSUS ALEATORIZADOS EN EL RENDIMIENTO DE HABILIDADES BOCCIA EN ATLETAS EXPERTOS CON PARÁLISIS CEREBRAL}

(Resumen)

La estructuración de las sesiones de entrenamiento con el fin de maximizar eficientemente el rendimiento deportivo se ha convertido en un tema importante en los últimos veinte años. Existen muy pocos estudios directamente relacionados con la boccia para atletas con parálisis cerebral (PC) y por lo tanto la información sobre las medidas de rendimiento es escasa. El objetivo de este estudio fue evaluar el efecto de programas de entrenamiento fijos y aleatorizados en el desempeño de las habilidades de boccia. Catorce atletas con experiencia a nivel nacional con parálisis cerebral $(\mathrm{M}=$ 23.6 años) participaron en este estudio. Los atletas fueron divididos en dos grupos de intervención y 
posteriormente asignados a horarios de entrenamiento fijos $(\mathrm{n}=$ siete atletas $)$ y aleatorios $(\mathrm{n}=$ siete atletas) durante 10 semanas. La recolección de datos incluye procedimientos iniciales de prueba pre-y post-test. La prueba de signos de Wilcoxon para muestras relacionadas y la prueba $U$ de Mann-Whitney fueron usadas para el análisis estadístico y sólo encontraron evidencias estadísticamente significativas para apoyar el horario fijo $(\mathrm{z}=2.29, \mathrm{p}=0,02, \mathrm{CI} .90=9.50,22.50)$. A pesar de ello, las conclusiones y los casos individuales de mejora, más los comentarios de atletas y entrenadores indican una significación práctica hacia los horarios de entrenamiento fijos sobre los aleatorizados, en términos de mejora de las habilidades de rendimiento en boccia. Mayores mejoras a lo largo de las tres habilidades de boccia medidas y en la diferencia media total entre el pre y posttest se mostraron a favor de los atletas que siguieron el horario de entrenamiento fijo.

PALABRAS CLAVE: parálisis cerebral (PC), boccia, habilidades motoras, horarios de entrenamiento fijos y aleatorizados.

\section{EFEITOS DAS SESSÕES DE TREINO BLOQUEADO VERSUS ALEATÓRIO AO NIVEL DA PERFORMANCE, EM ATLETAS EXPERIENTES DE BOCCIA COM PARALISIA CEREBRAL \\ (Resumo)}

A maximização eficiente da performance desportiva através da estruturação de sessões de treino tem sido, nos últimos vinte anos, objecto de muita atenção. O número de estudos existentes sobre a modalidade de Boccia para atletas com paralisia cerebral é muito reduzido e consequentemente a informação disponível sobre avaliação da performance é escassa. O objectivo do estudo é avaliar os efeitos das sessões de treino bloqueado versus aleatório na performance dos skills de boccia. Catorze atletas experientes de nível nacional com PC ( $M=23.6$ anos) participaram no estudo. Os atletas foram divididos em dois grupos experimentais e cumpriram sessões de treino bloqueado ( $\mathrm{n}=$ sete atletas) e sessões de treino aleatório $(\mathrm{n}=$ sete atletas) durante dez semanas. A recolha de dados incluiu a realização de pré e pós-testes segundo os procedimentos originais de avaliação. O teste de Wilcoxon para amostras emparelhadas e o teste U de Mann-Whitney apenas proporcionaram suporte para a existência de diferenças estatisticamente significativas nas sessões de treino bloqueado $\left(z=2.29, p=0.02, C I_{.90}=9.50,22.50\right)$. Apesar disto, os resultados e os casos individuais de melhoria bem como os comentários dos atletas e dos treinadores indicam uma significância prática a favor dos esquemas de treino bloqueado sobre os esquemas de treino aleatório em termos de melhoria dos skills de performance no boccia. As melhorias verificadas nos três skills avaliados e na diferença dos valores médios totais entre o pré e o pós-teste foram todas a favor dos atletas que cumpriram sessões de treino bloqueados.

Palavras chave: Paralisia cerebral (PC), boccia, skills motores, performance, sessões de treino bloqueado e aleatório 